\title{
Germination and initial development of canola and radish submitted to castor leaves aqueous extracts
}

\author{
Carlos Alberto Gonsiorkiewicz Rigon'*, Adriana Tourinho Salamoni², \\ Luan Cutti', Adalin Cezar Morais de Aguiar' \\ 'Federal University of Santa Maria, Frederico Westphalen, RS, Brazil \\ ${ }^{2}$ Federal University of Rio Grande, São Lourenço do Sul, RS, Brazil \\ *Corresponding author, e-mail: ca_rigon@hotmail.com
}

\begin{abstract}
This study aimed to evaluate the allelopathic activity of aqueous extracts of castor bean (Ricinus communis L.) leaves on germination and initial growth of canola (Brassica napus L.) and radish (Raphanus sativus L.) seedlings. Two experiments were conducted, usingcanola seeds for the first, which was installed in a $2 \times 7$ factorial scheme (with two photoperiods - dark and light and seven extracts concentrations - $0,1,2,4,8,16$ and $32 \%)$. The second experiment consisted of an evaluation of radish seed germination submitted to seven concentrations of the extracts in the dark photoperiod. The germination of the canola seeds was reduced in the dark, and the use of extracts at concentrations of $16 \%$ and $32 \%$ inhibited seeds germination for both studied photoperiods. The radish seed germination was completely inhibited when the concentration of $32 \%$ was used, however, at the concentrations of 4,8 and $16 \%$ a reduction on rootand hypocoyl development of the seedlings were observed, affirming the high allelopathic potential of castor bean aqueous extracts on canola and radish.
\end{abstract}

Keywords: allelopathy, Brassica napus, Raphanus sativus, Ricinus communis

\section{Germinação e desenvolvimento inicial de canola e nabo submetidas a extratos aquosos de folhas de mamona}

\section{Resumo}

Este estudo teve como objetivo avaliar a atividade alelopática de extratos aquosos de folhas de mamona (Ricinus communis L.) sobre a germinação e crescimento inicial de plântulas de canola (Brassica napus L.) e nabo forrageiro (Raphanus sativus L.). Dois experimentos foram conduzidos, o primeiro utilizando sementes de canola, realizado em esquema fatorial $2 \times 7$ (fotoperíodos - claro e escuro e concentrações de extratos - 0, 1, 2, 4, 8, 16 e 32\%); o segundo experimento, consistiu na germinação de sementes de nabo submetidas às sete concentrações dos extratos em fotoperíodo escuro. A germinação das sementes de canola foi reduzida no escuro, e os extratos nas concentrações de 16 e $32 \%$ inibiu a germinação das sementes, em ambos os fotoperíodos. A germinação das sementes de nabo foi completamente inibida na concentração de $32 \%$, no entanto, nas concentrações de 4, $8,16 \%$, houve uma redução do desenvolvimento da raiz e do hipocótilo das plântulas, afirmando assim, elevado potencial alelopático de extratos aquosos de mamona em canola e nabo forrageiro.

Palavras-chave: alelopatia, Brassica napus, Raphanus sativus, Ricinus communis 


\section{Introduction}

On the management of economically important crops, one of the main problems faced by farmers is the infestation of weeds, which brings severe consequences for crops productivity. During the winter, problems with infestation of radish (Raphanus sativus L.) are common for species such as oilseed rape (Brassica napus L.) radish(Silva et al., 2006). According to Theisen (2008), studies indicates that some biotypes of these species have resistance to acetolactate synthase inhibiting herbicides (ALS), which is the first enzyme in the amino acids synthesis pathway. The Intensive use of herbicides with the same active ingredient and the fact that radish is used as forage after the summer crop harvest intensified the spread of this species as weed, making necessary researches aiming the development of new control alternatives(Theisen, 2008 ).

The canola is a winter oilseed which belongs to the Brassicaceae family, featuring in their grain a great fatty acid composition for the human diet and is also used as an excellent supplement to the formulation of feed for poultry, pigs, and cattle (Tomm, 2007). It is the most grown oilseed in some countries, however, in Brazil, it has been gaining attention only in recent years due to the advent of the National Program for Biodiesel Production, aimed the production of fuels from vegetable oils (Vargas et al., 2011).

One of the main difficulties for growing canola in Brazil is the weed control (Vargas et al., 2011 ). Added to this, the herbicides indicated for use in post-emergence of the crop are scarce in the national market, making the control more difficult (Tomm, 2000). Thus, ecological alternatives have been studied, such as plants with allelopathic potential that would enable the production of natural herbicides.

Allelopathy refers to the release of some substances by plants in the environment that could have a harmful or beneficial effect on other plants, , Such substances can be essential oils, resins, alkaloids, flavonoids, tannins, among other compounds (Rice, 1984; Taiz \& Zeiger, 2004).

Some plants produce large allelopathic and power compounds that has been widely studied in order to obtain alternatives for the increasing use of chemicals in weeds control(Ohara, 1995). Other plants produce secondary metabolites, but are not able to inhibit or avoid other plant germination, depending on the species that produces the secondary metabolites and also the species which is receiving such allelopathic effect. Rigon et al. (2012) studying the allelopathic effect of radish leaves on the bean crop observed that the extracts of leaves did not inhibit castor bean germination. However, Rigon et al. (2014) studying the effect of radish leaves extracts observed an inhibitory potential of germination of invasive species such as Bidens pilosa $L$. and radish.

The castor bean (Ricinus communis L.) is a species of the Euphorbiaceae family that features an average of $49 \%$ of oil in their seeds. Furthermore, the seeds and the leaves contain a very toxic protein called ricin (Ohara, 1995; Rizzi et al., 2010). Added to this, its leaves, stems, seeds and roots have a large amount of flavonoids, tannins, and alkaloids, important secondary metabolites that can confer allelopathic potential on other species (Rana et al., 2012; Alugah \& lbraheem 2014).

The importance of this crop is increasing by the biofuelsproduction, but also for its use as a raw material for the chemical industry. It is also used in the composition of products as varnishes, paints, and plastics, as well as pesticide and fertilizer (Rizzi et al., 2010). However, studies regarding the allelopathic effect of this oilseed are scarce.

Based on the facts presented and the hypothesis that castor extracts hamper the germination and initial development only of radish radish, the aim of this study was to evaluate the allelopathic activity of castor leaves extracts on the germination and initial development of canola and radish seedlings.

\section{Material and methods}

Two studies were conducted in the laboratory of botany at the Federal University of Santa Maria campus of Frederico Westphalen, Brazil, RS. The species used as a source for the extracts preparation was the castor bean (Ricinus communis L.). As target species radish (Raphanus sativus L.) and canola (Brassica napus L.) were 
used.

The first experiment consisted of the evaluation of seed germination and initial development of canola seedlings on two photoperiods, with a $2 \times 7$ factorial. The first factor was the light and dark photoperiod and the second factor was the different concentrations of castor bean leaves extracts $(0,1,2,4,8,16$ and $32 \%)$. The second experiment consisted of the evaluation of the seed germination and initial development of radish seedlings submitted to different concentrations of castor bean extracts $(0,1,2,4,8,16$ and $32 \%)$, in dark photoperiod.

For the formulation of aqueous extracts, castor bean leaves were collected in experimental plantations of the University area, with plants in the vegetative stage. The leaves were dried in a circulating oven with forced air at $65^{\circ} \mathrm{C}$ until constant weight, during 72 hours, and ground for the preparation of extracts at concentrations of $1,2,4,8,16$ and $32 \%$. For the treatments, 1, 2, 4, 8, 16 and $32 \mathrm{~g}$ of ground castor bean leaves solubilized in $100 \mathrm{ml}$ of distilled water were used. For the control, (0\%) only distilled water was used. After the extracts formulation, the $\mathrm{pH}$ was measured unsing a pHmeter since a very acid or alkaline $\mathrm{pH}$ can damage the biochemical processes and seeds nutrition.

For both experiments a completely randomized design was used, and each experimental unit (EU) consisted of a gearbox with two germitest paper at the base, which were humidified in the ratio of 2.5 times their mass (Brazil, 2009), for each treatment - aqueous extracts. IFor each experimental unity, 25 seeds of both species were placed with four replicates each treatment, totaling 100 seeds per treatment. The gearbox were placed in a growth chamber type Biochemical Oxygen Demand (BOD), with controled photoperiod and temperature at $25 \pm$ $2^{\circ} \mathrm{C}$ for both species.

For both experiments daily germination ratings were carried out, from the first to the seventh day after the experiment installation. It was considered as germinated seed when 2 $\mathrm{mm}$ of root protrusion was observed (Ferreira \& Aquila 2000). The calculations of germination percentage $(G)$ and mean of germination time (GMT) were performed according to Labouriau
\& Valadares (1976) and the germination speed index (GSI) was obtained using the formula proposed by Fernandes et al. (2007). The evaluation of seedling development was carried out on the seventh day, analyzing the variables radicle length (RL) and hypocotyl length ( $\mathrm{HL})$, with data expressed in millimeters $(\mathrm{mm})$. The total fresh weight (TFW) was obtained after the weighing of the seedlings, with the results expressed in grams (g).

The data were submitted to variance analysis, and for the variable percentage of germination, the arcsine transformation $(x / 100)^{0.5}$ (Pimentel-Gomes, 1990) was used and for the other variables the applied transformation was $(x+1)^{0.5}$. The letter resulting from the transformed average were used. For variables with significant difference to the $F$ test, the means were compared according to Tukey's test, using 5\% of error probability for both tests. Statistical analysis were performed using the SISVARß software (FERREIRA, 2011).

\section{Results and discussion}

In Table 1 is possible to observe the pHs of the castor bean leaves extracts. The lowest $\mathrm{pH}$ value observed was 6.11 for the extract with $32 \%$ of concentration and the highest the 6.98 observed for the control. Thus, the $\mathrm{pH}$ of the extracts did not influence seeds germination, since the observed $\mathrm{pHs}$ are in the range of 6.0 to 7.5 , which is considered ideal and promotes biochemical processes and plant nutrition (Brazil, 2009).

Table 1. PH values of Ricinus communis extracts.

\begin{tabular}{cc}
\hline $\begin{array}{c}\text { Concentration of castor bean } \\
\text { extracts }\end{array}$ & $\mathrm{pH}$ \\
\hline Control & 6.98 \\
$1 \%$ & 6.87 \\
$2 \%$ & 6.79 \\
$4 \%$ & 6.47 \\
$8 \%$ & 6.35 \\
$16 \%$ & 6.30 \\
$32 \%$ & 6.11 \\
\hline
\end{tabular}

The averages related to the variables of germination of canola seed in both photoperiods tested are shown in Table 2. The seed extracts submitted to the light photoperiod resulted in the best germination percentages. However, extracts 
concentrations of 16 and $32 \%$ completely inhibited the germination in both environments. These data differ from the results founded by Barreto et al. (2011), which used soybean leaves extracts in concentrations of 0,5, 10, 15 and $20 \%$ on canola seeds. The authors observed that the extracts did not inhibit the seed germination, not differing from the control. Corsato et al. (2010) studying the allelopathic potential of extracts of fresh sunflower leaves on the germination of Bidens pilosa $\mathrm{L}$ and soybeans, at concentrations of $0,20,40,60,80$ and $100 \%$, observed that the Bidens pilosa $\mathrm{L}$ seed germination was totally inhibited by adding the extract of $40 \%$, while the germination of soybean seeds was not affected by increasing the concentration of solutions.

There was also the allelopathic effect on the germination speed index (GSI) reducing this ratio when the extracts concentration increased. Similar results were observed by Wandscheer \& Pastorini (2008), studying the allelopathic potential of different concentrations of Raphanus raphanistrum L. leaf and root extracts applied to lettuce seeds. The authors observed that increased concentrations of both extracts decreased the germination rate of the seed.

Table 2. Germination percentage (G), germination speed index (GSI) and mean germination time (MGT) of canola seeds submitted to aqueous extracts of Ricinus communis leaves in light and dark photoperiod.

\begin{tabular}{|c|c|c|c|c|c|c|c|c|}
\hline \multirow{3}{*}{$\begin{array}{c}\text { Treatments } \\
0 \%\end{array}$} & \multicolumn{3}{|c|}{ G (\%) } & \multicolumn{3}{|c|}{ (GSI) } & \multicolumn{2}{|c|}{ MGT (days) } \\
\hline & \multicolumn{2}{|c|}{ light } & dark & \multicolumn{2}{|c|}{ light } & dark & light & dark \\
\hline & 92.0 & $\mathrm{aA}^{*}$ & $66.0 \mathrm{aB}$ & 8.9 & $\mathrm{aA}$ & $6.1 \mathrm{aB}$ & $3.2 \mathrm{aB}$ & $3.9 \mathrm{aA}$ \\
\hline $1 \%$ & 73.0 & bA & $62.0 \mathrm{aB}$ & 6.8 & $\mathrm{bA}$ & $6.5 \mathrm{aA}$ & $3.8 \mathrm{aA}$ & $3.5 \mathrm{a} A$ \\
\hline $2 \%$ & 65.0 & bcA & $33.0 \mathrm{bB}$ & 5.7 & $\mathrm{bcA}$ & $3.4 \mathrm{bB}$ & $3.4 \mathrm{aA}$ & $3.6 \mathrm{a} A$ \\
\hline $4 \%$ & 58.0 & $c A$ & $24.0 \mathrm{bcB}$ & 4.4 & $c A$ & $1.7 \mathrm{bcB}$ & $3.8 \mathrm{aA}$ & $4.0 \mathrm{a} A$ \\
\hline $8 \%$ & 28.0 & $\mathrm{dA}$ & $18.0 \mathrm{CB}$ & 1.4 & $\mathrm{dA}$ & $1.4 \mathrm{cA}$ & $5.0 \mathrm{bA}$ & $3.6 \mathrm{aB}$ \\
\hline $16 \%$ & 0.0 & eA & $0.0 \mathrm{dA}$ & 0.0 & $d A$ & $0.0 \mathrm{cA}$ & $0.0 \mathrm{cA}$ & $0.0 \mathrm{bA}$ \\
\hline $32 \%$ & 0.0 & $\mathrm{eA}$ & $0.0 \mathrm{dA}$ & 0.0 & $\mathrm{dA}$ & $0.0 \mathrm{cA}$ & $0.0 \mathrm{cA}$ & $0.0 \mathrm{bs}$ \\
\hline Mean & 45.1 & $A$ & $29.0 \quad B$ & 3.9 & $A$ & $2.7 \mathrm{~A}$ & $2.7 \quad \mathrm{~A}$ & $2.6 \mathrm{~A}$ \\
\hline \multirow[t]{2}{*}{$\mathrm{CV}(\%)$} & \multicolumn{2}{|c|}{20.4} & 11.2 & \multicolumn{2}{|c|}{12.1} & 8,8 & 6.5 & 5.3 \\
\hline & \multicolumn{8}{|c|}{ Mean Square } \\
\hline Photoperiod (P) & \multicolumn{3}{|c|}{$30.04^{* *}$} & \multicolumn{3}{|c|}{$7.47^{\text {ns }}$} & \multicolumn{2}{|c|}{$0.34^{\text {ns }}$} \\
\hline Extract (E) & \multicolumn{3}{|c|}{$198.94^{* *}$} & \multicolumn{3}{|c|}{$98.31^{* *}$} & \multicolumn{2}{|c|}{$165.61^{* *}$} \\
\hline Factor $\mathrm{P} X \mathrm{E}$ & \multicolumn{3}{|c|}{$10.76^{* *}$} & \multicolumn{3}{|c|}{$4.93^{* *}$} & \multicolumn{2}{|c|}{$4.99 * *$} \\
\hline
\end{tabular}

According to Gonzalez et al. (2002), , the penetration of some allelopathic substances together with the water may occur in the germination process, fact that can inhibit or even retard the cells multiplication. Therefore, it is important to consider the germination delay, as seen in this study, being important the daily monitoring of seeds germination since the allelopathic effect does not occur only on the germination, but in other biochemical processes.

The lowest MGT was observed in the light photoperiod without the use of any extract (control) and the largest MGT was obtained by seeds submitted to light photoperiod, with the amount of $8 \%$ of leaves extract.

Similar results were founded by Rickli et al. (2011) using concentrations of 0 to $100 \%$ of dried leaves of Azadirachta indica A. Juss aqueous extracts. On Bidens pilosa L. the authors noted that the use of the extract in the concentration of $20 \%$ resulted in an increase on MGT, which was statistically different from the control. According to Ferreira \& Aquila (2000) the use of extracts in some concentrations can not inhibit the germination but can difficult the process, leading to anincrease in the germination time and decrease in the germination rate, possibly damaging the seedlings structure.

On Table 3 the average values of the variables related to the initial development of canola seedlings submitted to castor bean extracts are shown. The seedlings submitted to dark presented bigger radicle (RL) and hypocotyl (LH) lenght and also higher total fresh weight (TFW). In both photoperiods, the increasing concentration of the extract resulted in a reduction in length and weight values. These results corroborate with those observed by 
Barreto et al. (2011) who observed a decrease in radicle length of canola seedlings submitted to increasing concentrations of soybean leaves extracts. According to the authors, the length of the radicle is an excellent parameter to observe the allelopathic influence, since this plant organ is very sensitive and is in direct contact with the extracts.

It was also observed that the seeds submitted to extracts of 1 and $2 \%$ of concentration and for both photoperiods, showed higher hypocotyl length than the control.

However, only those submitted to dark photoperiod differ significantly from others, demonstrating certain stimulus and indicating that the extracts applied at low concentrations may be associated with an increase in cell division.

Table 3. Radicle length (RL), hypocotyl length (HL) and total fresh weight (TFW) of canola seedlings submitted to Ricinus communis aqueous extracts from the leaves andto light and dark photoperiod.

\begin{tabular}{|c|c|c|c|c|c|c|c|c|c|c|}
\hline \multirow{3}{*}{$\begin{array}{c}\text { Treatments } \\
0 \%\end{array}$} & \multicolumn{4}{|c|}{ RL (mm) } & \multicolumn{3}{|c|}{$\mathrm{HL}(\mathrm{mm})$} & \multicolumn{3}{|c|}{ TFW (mg) } \\
\hline & \multicolumn{2}{|c|}{ light } & \multicolumn{2}{|c|}{ Dark } & \multicolumn{2}{|c|}{ light } & dark & \multicolumn{2}{|c|}{ light } & dark \\
\hline & 49.7 & $a B^{*}$ & 62.3 & $a A$ & 20.0 & $a B$ & $33.0 \mathrm{bA}$ & 0.4 & $a B$ & $0.5 \mathrm{aA}$ \\
\hline $1 \%$ & 46.3 & $a A$ & 54.8 & $a A$ & 25.0 & $a B$ & 42.7 aA & 0.3 & $b B$ & $0.4 \mathrm{aA}$ \\
\hline $2 \%$ & 43.4 & $a A$ & 33.1 & $b B$ & 26.7 & $a B$ & $48.8 \mathrm{aA}$ & 0.3 & $a b A$ & $0.2 \mathrm{bB}$ \\
\hline $4 \%$ & 27.6 & $\mathrm{bA}$ & 23.2 & bcA & 18.2 & $a b B$ & $27.0 \mathrm{bA}$ & 0.2 & bA & $0.15 \mathrm{bcB}$ \\
\hline $8 \%$ & 17.1 & $\mathrm{bA}$ & 16.3 & $c A$ & 10.2 & bA & $15.9 \mathrm{CA}$ & 0.1 & $C A$ & $0.1 \mathrm{cdA}$ \\
\hline $16 \%$ & 0.0 & $C A$ & 0.0 & $d A$ & 0.0 & $C A$ & $0.0 \mathrm{dA}$ & 0.0 & $C A$ & $0.0 \mathrm{dA}$ \\
\hline $32 \%$ & 00.0 & $\mathrm{CA}$ & 0.0 & $d A$ & 0.0 & $\mathrm{CA}$ & $0.0 \mathrm{dA}$ & 0.0 & CA & $0.0 \mathrm{dA}$ \\
\hline Mean & 26.3 & A & 27.1 & $A$ & 14.3 & A & 23.9 A & 0.2 & A & $0.1 \quad A$ \\
\hline \multirow[t]{2}{*}{$\mathrm{CV}(\%)$} & \multicolumn{2}{|c|}{5.6} & \multicolumn{2}{|c|}{10.0} & \multicolumn{2}{|c|}{6.3} & 9.6 & \multicolumn{2}{|c|}{3.69} & 2.43 \\
\hline & \multicolumn{10}{|c|}{ Mean Square } \\
\hline Photoperiod(P) & \multicolumn{4}{|c|}{$0.70^{\text {ns }}$} & \multicolumn{3}{|c|}{$173.47^{* *}$} & \multicolumn{3}{|c|}{$0.752^{\mathrm{ns}}$} \\
\hline Extract (E) & \multicolumn{4}{|c|}{$122.17^{* *}$} & \multicolumn{3}{|c|}{$98.01^{* *}$} & \multicolumn{3}{|c|}{$70.79 * *$} \\
\hline Factor PxE & \multicolumn{4}{|c|}{$3.472^{* *}$} & \multicolumn{3}{|c|}{$7.57^{* *}$} & \multicolumn{3}{|c|}{$3.766^{* *}$} \\
\hline
\end{tabular}

Tur et al. (2010) using concentrations from 0 to $4 \%$ of leaves and fruit extracts of Duranta repens on Lactuca sativa, observed that the seedlings fresh weight also decreased with the increase of the concentrations. Hoffman et al. (2007) mentioned that the reduction of fresh weight is a reflection of the reduction of roots and aerial parts. It confirms the data presented in this paper where there was a reduction of radicle and hypocotyl length; this reduction was associated with the decrease of seedlings total fresh weight.

The results regarding the cradish germination variables are presented on Table 4. It was noted a total inhibition of seed germination with the application of the extract at a concentration of $32 \%$, but with the aplications of extracts with doses of $8 \%$ and $16 \%$ is possible to observe the a significantly inhibition of the germination. Corsato et al. (2010) using extracts of fresh sunflower leaves on Bidens pilosa $\mathrm{L}$ at concentrations of $20,40,60,80$ and $100 \%$, observed that the extract in the concentration of $20 \%$ difficults the germination and extracts with the concentration of $40 \%$ completely inhibited Bidens pilosa $\mathrm{L}$ seed germination. According to Ferreira \& Aquila (2000), compounds with allelopathic potential act as development inhibitors of radicles and hypocotyls.

Table 4. Germination percentage (G), germination speed index (GSI) and mean germination time (MGT) of radish seeds submitted to aqueous extracts of Ricinus communis leaves.

\begin{tabular}{ccccccc}
\hline Treatments & $\mathbf{G}(\%)$ & \multicolumn{2}{c}{ GSI } & $\begin{array}{c}\text { MGT } \\
\text { (days) }\end{array}$ \\
\hline $0 \%$ & 91.00 & $\mathrm{a}$ & 19.39 & $\mathrm{~A}$ & 1,55 & $\mathrm{a}$ \\
$1 \%$ & 88.00 & $\mathrm{a}$ & 16.85 & $\mathrm{~A}$ & 1,70 & $\mathrm{a}$ \\
$2 \%$ & 94.00 & $\mathrm{a}$ & 16.82 & $\mathrm{~A}$ & 1,63 & $\mathrm{a}$ \\
$4 \%$ & 95.00 & $\mathrm{a}$ & 11.87 & $\mathrm{~B}$ & 2,35 & $\mathrm{a}$ \\
$8 \%$ & 65.00 & $\mathrm{~b}$ & 5.28 & $\mathrm{C}$ & 3,95 & $\mathrm{~b}$ \\
$16 \%$ & 8.00 & $\mathrm{C}$ & 1.01 & $\mathrm{Cd}$ & 2,70 & $\mathrm{ab}$ \\
$32 \%$ & 0.00 & $\mathrm{C}$ & 0.00 & $\mathrm{D}$ & 0,00 & $\mathrm{C}$ \\
\hline Mean & 63.00 & 10.18 & 1.98 \\
CV (\%) & 6.29 & 9.26 & 6.29 \\
\hline Means followed by the same letter in the column do not differ by Tukey's test at 5\%
\end{tabular}
probability of error.

Gatti et al. (2004), using different extracts of Aristolochia esperanza onRaphanus sativus germination, observed that the leaves extracts on the concentration of $75 \%$ resulted in inhibitory 
effects on the germination rate. The same authors found that stem, root and fruit extracts did not influence the seeds germination percentage. In contrast, Gao et al. (2009) observed that extracts of Hemisepta lyrata can cause inhibitory effects on Raphanus sativus seeds germination, despite the concentration.

It is observed in Table 4 that the germination speed index values (GSI) also presented a relation between the extracts concentrations. The presence of the extract at concentrations of 4,8 and $16 \%$ resulted in significantly lower GSI when compared to control and to the extracts with $1 \%$ and $2 \%$ of concentration. In the same way, Borella et al. (2012) using extracts of Piper mikanianum on Raphanus sativus observed the negative effect in GSI with increasing extracts concentrations (from 0 to $8 \%$ ).

The results of the mean germination time (MGT) (Table 4) showed a significant increase of this variable when the extract at $8 \%$ of concentration was used. For other treatments, there was no significant difference, compared to the control. These results are in accordance to the assertions that with the absorption of water by the seed there is also allelochemicals penetration, which somehow slow down the cell division, and are related to the increase allelochemicals amount whenhigher concentration solutions are applied. However, some species have defenses in the germination process against certain allelochemicals. Mauli et al. (2009), using extracts of different concentrations of Leucaena leucocephala on Ipomea grandifolia, Sida rhombifolia, Bidens pilosa and Glycine max, founded that S. rhombifolia and B. pilosa extracts did not change the MGT of the seeds, not differing from control. It was also found that I. grandifolia and G. max seeds presented the highest MGT values when submitted to higher extracts concentrationss.

The variables related to the initial development of radish seedlings are shown on Table 5. There was a significant decrease in the radicle length (RL) and hypocotyl $(\mathrm{HL})$ and lower total fresh weight (TFW) whenextracts of $8 \%$ and $16 \%$ of concentration were used, and also that the same concentrations reduced the seed germination percentage. It was visible in the study a darkening of the seedlings radicles and the appearance of abnormal seedlings in the same concentrations. According to Ferreira \& Aquila (2000), the allelochemicals can induce abnormalities in the seedlings and necrosis in roots, which are considered the most common symptoms. It can be explained since these parts of the seedlings are in direct contact with the solutions (Chung et al., 2001). For HL, Wandscheer \& Pastorini (2008) founded similar results with the use of different concentrations of radish extracts on lettuce seedlings. However, Borella et al. (2011) using Solanum americanum extracts on Raphanus sativus seeds, observed that $\mathrm{HL}$ was not affected by the increase of extracts concentration. According to the authors, it occurs because the aerial part is not directly connected to the extracts absorption, being less sensitive to allelopathic effects.

Table 5. Radicle length (RL), hypocotyl length $(\mathrm{HL})$ and total fresh weight (TFW) of radish seedlings submitted to aqueous extracts of of Ricinus communis leaves.

\begin{tabular}{|c|c|c|c|}
\hline Treatments & $\mathrm{RL}(\mathrm{cm})$ & $\mathrm{HL}(\mathrm{cm})$ & TFW (g) \\
\hline $0 \%$ & $3.76 \quad B$ & $2.81 \quad B$ & $1.45 \mathrm{ab}$ \\
\hline $1 \%$ & $5.75 \mathrm{~A}$ & $3.83 \mathrm{~A}$ & $1.65 \mathrm{a}$ \\
\hline $2 \%$ & $6.12 \mathrm{~A}$ & $3.99 \mathrm{~A}$ & $1.76 \mathrm{a}$ \\
\hline $4 \%$ & $4.38 \mathrm{~B}$ & $2.72 \quad B$ & $1.15 \mathrm{~b}$ \\
\hline $8 \%$ & $1.54 \mathrm{C}$ & $0.79 \mathrm{C}$ & $0.38 \mathrm{C}$ \\
\hline $16 \%$ & $0.30 \mathrm{D}$ & $0.31 \mathrm{Cd}$ & $0.02 \mathrm{~d}$ \\
\hline $32 \%$ & $0.00 \mathrm{D}$ & $0.00 \quad \mathrm{D}$ & $0.00 \mathrm{~d}$ \\
\hline Mean & 3.12 & 2.10 & 0.91 \\
\hline$C \vee(\%)$ & 7.58 & 6.93 & 3.72 \\
\hline
\end{tabular}

As can be seen in Table 5, the lower concentrations stimulated the growth of root and aerial parts. This stimulus has been extensively studied in allelopathy experiments. According to Rice (1984), this process is directly related to the influence of the extract on the fitohormonal production of target species, or there is an increase in the sensitivity of their tissues. Other authors, such as Hong et al. (2004), affirm that this stimulus is a defense mechanism to lower concentrations of the extracts. Borella et al. (2011) observed that the Solanum americanum extracts provided higher values of fresh weight of radish seedlings, compared to the control, due to the stimulus occurred in the development 
of shoots, corroborating with the findings of this study.

\section{Conclusions}

Extracts of castor beans leaves (Ricinus communis L.) have an obvious allelopathic effect on the germination and initial development of canola seedlings (Brassica napus L.) for both tested photoperiod.

The germination and initial seedling development of radish (Raphanus sativus L.) are inhibited with an increase of the extract concentration.

\section{References}

Alugah, C.I., Ibraheem, O. 2014. Whole plant screenings for flavonoids and tannins contents in Castor plant (Ricinus communis L.) and evaluation of their biological activities. International Journal of Herbal Medicine 2: 68-76.

Barreto, B.C.P., Santos, R.F., Viecelli, C.A., Trés, S.P., Oliveira, M.C. 2011 . Interferência alelopática de extrato da soja sobre sementes de canola e crambe. Cultivando o Saber 4: 188-198.

Borella, J., Martinazzo, E.G., Aumonde, T.Z., Amarante, L., Moraes, D.M., Villela, F.A. 2012. Resposta na germinação e no crescimento inicial de rabanete sob ação de extrato aquoso de Piper mikanianum (Kunth) Steudel. Acta Botânica 26: 415-420.

Borella, J., Wandscheer, A. C. D., Pastorini, L.H. 2011. Potencial alelopático de extratos aquosos de frutos de Solanum americanum Mill. Sobre as sementes de rabanete. Revista Brasileira de Ciências Agrárias 6: 309-313.

Brasil. Ministério da Agricultura, Pecuária e Abastecimento. 2009. Regra para Análise de Sementes. Mapa/ACS, Brasília, Brasil. 399p.

Chung, I.M., Ahn, J.K., Yun, S.J. 2001. Assessment of allelopathic potential of barnyard grass (Echinochloa crus-gall) on rice (Oriza sativa L.) cultivars. Crop Protection 20: 921-928.

Corsato, J.M., Fortes, A.M.T., Santorum, M., Leszczynski, R. 2010. Efeito alelopático do extrato aquoso de folhas de girassol sobre a germinação de soja e picão- preto. Semina - Ciências Agrárias 31: 353-360.

Fernandes, L. de A.V., Miranda, D.L.C. de, Sanquetta, C.R. 2007. Potencial alelopático de Merostachys multiramea hackel sobre a germinação de Araucaria angustifolia (bert.) kuntze. Revista Acadêmica 5: 139-146.

Ferreira, D. F. 2011 . Sisvar: a computer statistical analysis system. Ciência e Agrotecnologia 35: 1039-1042.

Ferreira, A.G., Aquila, M.E.A. 2000. Alelopatia: Uma área emergente da ecofisiologia. Revista Brasileira Fisiologia Vegetal 12: 175-204.

Gao, X., Li, M., Gao, Z., Li, C., Sun, Z. 2009. Allelopathic effects os Hemistepta Lyrata on the germination and growth of wheat, sorghum, cucumber, rape, and radish seeds. Weed Biology and management 9: 243-249.

Gatti, A.B., Perez, S.C.J.G. de A., Lima, M.I.S. 2004. Atividade alelopática de extratos aquosos de Aristolochia esperanzae 0 . Kuntze na germinação e no crescimento de Lactuca sativa L. e Raphanus sativus L. Acta Botânica Brasileira 18: $459-472$

Gonzalez, H.R., Mederos, D.M., Sosa, I.H. 2002. Efectos alelopáticos de restos de diferentes espécies de plantas medicinales sobre la albahaca (Ocimum basilicum L.) em condiciones de laboratório. Revista Cubana de Plantas Medicinales 7: 67-72.

Hoffmann, C.E.F., Nevez, L.A.S., Bastos, C.F., Wallau, G. da L. 2007. Atividade alelopática de Nerium oleander L. e Dieffenbachia picta Schott em sementes de Lactuca Sativa L. e Bidens pilosa L. Revista de Ciências Agroveterinárias 6: 11-21.

Hong, N.H., Xuan, T.D., Eiji, T., Khanh, T.D. 2004. Paddy weed control by higher plants from Southeast Asia. Crop Protection 23: 255-261.

Labouriau, L.G., Valadares, M.E.B. 1976. On the germination of seeds Calotropis procera (Ait.) Ait.f. Anais da Academia Brasileira de Ciências 48: 263-284.

Mauli, M.M., Fortes, A.M.T., Rosa, D.M.R., Piccolo, G., Marques, D.S., Corsato, J.M., Leszczynski, R. 2009. Alelopatia de Leucena sobre soja e plantas invasoras. Semina Ciências Agrárias 30: 55-62.

Ohara, G.H., Kojima, K.E., Rossi, J.C., Telles, M., Soares, T.V.C., Salomão, C., Sanda, M. 1995. Estudo experimental da biocompatibilidade do polímero poliuretano da mamona implantada intraóssea e intra-articular em coelhos. Acta Ortopédica Brasileira 3: 62-68.

Pimentel-Gomes, F. P. 1990. Curso de Estatística experimental. Nobel, São Paulo, Brasil. 468p.

Rana, M., Dhamija H. , Prashar B., Sharma S. 2012. Ricinus communis L. - A Review. International Journal of PharmTech Research 4: 1706-1711.

Rigon, J.P.G., Capuani, S., Cgerubin, M. R., Wastowski, A. D., Rosa, G.M. da. Allelopathic effects of aqueous extract of Brassica napus on germination of seeds of Phaseolus vulgaris. 2012. 
Revista Brasileira de Ciências Agrárias 7: 451-455.

Rigon, C.A.G., Salamoni, A.T., Cutti, L., Aguiar, A.C.M. 2014. Germinação e desenvolvimento inicial de picão-preto e nabo forrageiro submetidos a extratos de canola. Tecnologia \& Ciência Agropecuária 8: 25-28.

Rice, E. L. Allelopathy. 1984. Academic Press, New York, USA. 422p.

Rickli, H.C., Fortes, A.M.T., Silva, P.S.S., Pilatti, D.M., Hutt, D.R. 2011. Efeito alelopático de extrato aquoso de folhas de Azadirachta indica A. Juss. em alface, soja, milho e picão-preto. Semina Ciências Agrárias 32: 473-484.

Rizzi, B.S., Silva, G.A.J., Maior, T.S. 2010. Mamona como biocombustível. Revista de divulgação do Projeto Universidade Petrobras e IF Fluminense 1: 317-320.

Silva, S.O., Matsumoto, S.N., Bebé, F.V., José, A.R.S. 2006. Diversidade e frequência de plantas daninhas em associações entre cafeeiros e grevileas. Coffee Science 1: 126-134.

Taiz, L., Zeiger, E. 2004. Fisiologia vegetal. Artmed, Porto Alegre, Brasil. 722p.

Theisen, G. 2008. Aspectos botânicos e relato da resistência de nabo silvestre aos herbicidas inibidores de ALS. Documentos Embrapa 239. http://www.cpact.embrapa.br/publicacoes <Access: Jun 2nd, 2012>

Tomm, G.O. 2007. Indicativos tecnológicos para a produção de canola no Rio Grande do Sul. Embrapa Trigo, Passo Fundo, Brasil. 68 p.

Tomm, G.O. 2000. Situação atual e perspectivas da canola no Brasil. Documentos Embrapa 58. http://www.cnpt.embrapa.br/biblio/p_co58.htm <Access: Jun 9, 2012>

Tur, C.M., Borella, J., Pastorini, L.H. 2010. Alelopatia de extratos aquosos de Duranta repens sobre a germinação e o crescimento inicial de Lactuca sativa e Lycopersicum esculentum. Biotemas 23: 13-22.

Vargas, L., Tomm, G.O., Ruchel, Q., Kaspary, T.E. 2011. Seletividade de herbicidas para a canola PFB-2. Documentos Embrapa 130. http:// www.cnpt.embrapa.br/biblio/do/p_do 130.htm <Access: Jun 12, 2012>

Wandscher, A.C.D.; Pastorini, L.H. 2008. Interferência alelopática de Raphanus raphanistrum L. sobre a germinação de Lactuca sativa L. e Solanum lycopersicon L. Ciência Rural 38: 949-953. 